\title{
Jun'ichrō Tanizaki, Pochwała cienia, przeł. H. Lipszyc, Wydawnictwo Karakter, Kraków 2016, ss. 80; Shūzō Kuki, Struktura iki, przeł. H. Lipszyc, Wydawnictwo Karakter, Kraków 2017, ss. 128; Okakura Kakuzō, Księga herbaty, przeł. M. Kwiecieńska-Decker, Wydawnictwo Karakter, Kraków 2017, ss. 96
}

DOI: http://dx.doi.org/10.12775/RF.2018.020

Pod koniec 2016 roku ukazała się nakładem Wydawnictwa Karakter książka Jun'ichrō Tanizaki, Pochwała cienia, która zapoczątkowała serię trzech, przynajmniej jak do tej pory, pozycji. Wszystkie trzy książki poświęcone są estetyce japońskiej. Łączy je nie tylko tematyka, ale i szata graficzna. Wydania mają niewielki, bardzo poręczny format, z okładkami o stonowanej kolorystyce, z oszczędna, a jednocześnie niezwykle wyrazistą grafiką autorstwa Masakazu Miyanagi, przedstawiającą oryginalne tytuły książek zapisanych w stylu klasycznej kaligrafii japońskiej znakami kanji. Ten prosty zabieg estetyczny kieruje wyobraźnię czytelników na skojarzenia z kakemono, tradycyjnymi obrazami-zwojami używanymi często przy aranżacji wnętrz. Pozwalam sobie rozpoczać recenzowanie od omówienia strony graficznej edycji, nie zaś od przedstawienia treści, ale zważywszy na fakt, że cała seria dotyczy w znacznej mierze wrażliwości estetycznej, mam nadzieję, iż czytelnicy wybaczą mi to odstępstwo od reguł pisania recenzji wydawniczych.

Nazwiska autorów omawianych tu książek stanowią ciekawe i różnorodne zestawienia odmiennych, choć jednocześnie dopełniających się spojrzeń na kulturę japońską. Jun'ichrō Tanizaki, chyba najbardziej znany z całej trójki, jest utytułowanym i uznanym na świecie pisarzem, Shūzō Kuki jest filozofem i estetykiem, Okakura Kakuzō zaś jest znawcą sztuki japońskiej. Każdy z pisarzy gwarantuje zatem inny sposób spojrzenia na przepojoną estetyzmem kulturę japońską. Każdy z nich także był mocno związany z cywilizacją Zachodu w okresie największego obopólnego wpływu obu kultur na siebie, a efektem ich fascynacji i rozczarowań są niniejsze pozycje. Łączy je też nietypowa dla europejskiego sposobu pisania forma literacka, którą trudno sklasyfikować jako 
rozprawę, książkę czy dysertację, są to raczej rozmyślania, refleksje lub zapiski. Wydawca naprawdę musiał się postarać, aby znaleźć dla tej formy literackiej odpowiedni kształt wydawniczy. W ten sposób powstały niedużego formatu książeczki, które postaram się tu omówić chronologicznie.

Najstarsze są rozważania Okakura Kakuzō zawarte w zapiskach zatytułowanych Księga herbaty, wydanych w 1906 roku w języku angielskim jako The Book of Tea. Całość luźno skomponowanych rozmyślań, zamkniętych w siedmiu esejach, osnuta jest wokół ceremonii picia herbaty. Japońskie rozważania estetyczne autora wpisane są $\mathrm{w}$ religię, filozofię i styl życia. Możemy zatem znaleźć w niej informacje o historii powstania herbatyzmu, opowieści o największych mistrzach ceremonii herbacianej, ale także o architekturze pawilonów herbacianych i o sztuce ikebany, a wszystko to zanurzone głęboko w religijności taoistycznej i filozofii zen. Autor nawiązując do historii, sztuki i filozofii, wyczarował okno, przez które Europejczyk może podejrzeć nieco specyfikę myślenia Dalekiego Wschodu. Tytuł esejów Księga herbaty może być mylący dla ścisłego umysłu Europejczyka, który spodziewałby się dokładnego sprawozdania z historii powstania rytuału picia herbaty, chronologicznego katalogu naczyń związanych z tą ceremonia, precyzyjnych zaleceń prawidłowego sposobu sporządzania napoju itp. Tak naprawdę ani historia, ani rytuał picia herbaty nie jest tematem utworu, ale symbolicznym obrazem zbudowanym przez autora po to, byśmy mogli ujrzeć i być może zrozumieć rolę rytuału wprzęgniętego w medytację wyjątkowości dnia powszechnego. Wiele z naszych czynności powtarzanych codziennie urasta z czasem do rangi mniej lub bardziej znienawidzonego przez Europejczyka rytuału. Kultura wschodnia umiała z tej prozy, codzienności, pozornej przeciętności stworzyć swoistego rodzaju medytację, która, zamiast wpychać nas w utarte schematy, stwarza możliwość do refleksji nad ludzką egzystencją. Poprzez ceremonię picia herbaty Okakura Kakuzō pokazuje nam do jak odmiennych świadomości kulturowych należymy, jak różne są nasze sposoby myślenia i postrzegania świata oraz nas samych. Nie mamy wątpliwości, że ten sposób myślenia na zawsze pozostanie zamknięty przed człowiekiem cywilizacji zachodniej, choć jednocześnie pozostawia nam możliwość ujrzenia tajemniczego ogrodu przez uchyloną furtkę. W ten sposób udało mu się zaczarować i wpłynąć bezpośrednio na wiele osób naszej kultury, m.in. choćby na filozofię Martina Heideggera.

Z osobami Okakura Kakuzō i Martina Heideggera łączy się nazwisko Shūzō Kuki, autora rozważań zatytułowanych Struktura iki. Pierwszego z nich sam autor nazywał mianem duchowego ojca, drugiego można by chyba określić jako ojca metodologii. Chociaż japoński filozof inspiruje się także filozofią Hegla i Husserla, to w samej językowej strukturze rozważań wyraźnie widać wpływ Heideggera. Eseje Kuki nie 
są już tak lekkie jak refleksje wcześniej omawianego Kakuzō, stanowią jednak nie lada gratkę dla zdyscyplinowanego umysłu filozoficznego. Mamy bowiem do czynienia z klasycznymi esejami estetycznymi. Nie ma tu także zaskakujących niespodzianek, tytuł książki zdradza nam to, co zawierać będzie treść. Autor próbuje przybliżyć czytelnikowi pole znaczeniowe japońskiego terminu $i k i$, badając, w jaki sposób jest ono zakorzenione w świadomości Japończyków. Co zatem oznacza ów termin? Mniej więcej tyle co szyk, elegancja, wytworność, ale i zalotność, kokieteryjność czy też erotyczny powab. Autor próbuje przybliżyć czytelnikowi owo znaczenie przez odwoływanie się do języka francuskiego, niemieckiego i angielskiego, potem zaś ukazuje, w jaki sposób funkcjonuje ono w różnych sferach życia Japonii, w stosunkach damsko-męskich, ale także jako ideał „drogi wojownika” czy też element ogłady towarzyskiej, gdzie owa początkowa wytworność zmienia się w hart i zdolność do wyrzeczeń. Trzeci rozdział stanowi pewnego rodzaju strukturalny podział kategorii estetycznych na te, które są blisko i daleko od źródłowo omawianej wartości. Z napięć poszczególnych przeciwieństw rodzi się rozumienie. Mamy zatem do czynienia z bardzo eleganckim zabiegiem sytuującym się metodologicznie pomiędzy Heglowską dialektyką a Heideggerowskim rozjaśnianiem prawdy. Na koniec autor pokazuje nam, w jaki sposób omawiana kategoria istnieje w naturalnych ekspresjach życia ludzkiego i w sztuce. Mianem iki określimy zatem lekki deszcz, zalotne spojrzenie, delikatny makijaż, cienką tkaninę, smukłą kibić, lekkie wygięcie dłoni lub jej odwrócenie. Wszystkie te zjawiska oznaczają naturalną manifestację $i k i$. W sztuce opis funkcjonowania $i k i$ jest dużo trudniejszy do opisania. Dochodzi bowiem jeszcze kwestia znaczeń kulturowych nawarstwionych nawet we wzornictwie artystycznym. Opis układu linii dokonany przez japońskiego autora jest równie precyzyjny jak osiemnastowieczna wykładnia Hogartha przeprowadzona w Analizie piękna. Układ tych linii jest chyba najlepiej oddany w architekturze pawilonów herbacianych, w atmosferze kompozycji przestrzeni i światła, sytuującej się pomiędzy zalotnością i melancholią. Patrząc okiem estetyka europejskiego, nie mogę oprzeć się wrażeniu, że struktura $i k i$ najbardziej przypomina obraz trzech gracji tworzących razem jednorodne wyobrażenie wdzięku, trzech emocji różnych, czasem sobie pokrewnych, czasem pozostających w opozycji, a jednak niezbędnych do zbudowania ostatecznego nastroju lekkości, elegancji i żywości.

Ostatnia pozycja to książka Jun'ichrō Tanizaki zatytułowana Pochwała cienia. Swoją kompozycją przypomina nieco spostrzeżenia Kakuzō, ponownie mamy bowiem do czynienia ze swobodną formą zwaną w Japonii zuihitsu, co można tłumaczyć jako „za pędzlem”. Zgodnie z słusznym moim zdaniem spostrzeżeniem tłumacza można ją przyrównać do Prób Montaign'a. Z wszystkich trzech pozycji ta jest najluźniejsza kompozycyjnie, refleksje gonią spostrzeżenia, a historyjki płynnie przechodzą we 
wnioski, by znów rozpaść się i zanurzyć w odczuciach. W przypadku esejów Kakuzō mamy do czynienia z pewnym zabiegiem metaforycznego przeniesienia, symbolicznym odczytaniem kultury Japonii poprzez medytacyjną ceremonię przygotowywania herbaty. Dominuje zatem jeden temat, który rozchodzi się na wiele spostrzeżeń i splatających się ze sobą historii. Jeśli chodzi o Pochwatę cienia sytuacja jest nieco odmienna, autor snuje bowiem szereg impresji i refleksji, które płynnie przeplatają się ze sobą i uzupełniaja jednak jakby mimochodem, jakby bez zobowiązań wobec swych poprzedników. Tematem przewodnim japońskich "prób" jest estetyka cienia istniejąca zarówno w sztuce, jak i w życiu codziennym. Myśli autora biegną „za pędzlem” od architektury po wyroby z laki i nefrytu, od wygódki po świątynie, od patyny po teatr japoński, od zacienionych wnętrz po starość człowieka. Z tych rozważań przebłyskuje opowieść o Japonii, ale i o kulturze Zachodu, o różnicach istniejących między nimi. W eseju Piękno w mroku autor wyraźnie przeciwstawia wschodnią estetykę cienia zachodniemu upodobaniu do światła. Pomimo daleko idącego uproszczenia i mocnego zindywidualizowania spostrzeżeń autora nie mogę oprzeć się wrażeniu, że tak jest w istocie. Mrok dla Europejczyka jest zawsze czymś niepokojącym, tajemniczym, a niekiedy nawet przerażającym, natomiast słowo „oświecenie" ma jednoznacznie pozytywne konotacje. Jak zauważa Tanizaki, nawet duchy zachodniego człowieka są białe i przezroczyste, jakby zrobione ze szkła.

Należy jeszcze dodać, że wszystkie trzy książki wyszły spod pióra znakomitych tłumaczy. Księga herbaty została przełożona przez Marię Kwiecieńską-Decker z języka angielskiego, pozostałe pozycje z języka japońskiego przez Henryka Lipszyca, znakomitego japonistę, który dodał do nich także świetnie napisane wprowadzenia.

Kinga Kaśkiewicz

Uniwersytet Mikołaja Kopernika, Toruń e-mail: Kinga.Kaskiewicz@umk.pl 